\title{
POSSIBLE 2020 REGIONAL HEAD ELECTIONS AS A RESPONSE TO THE COVID 19 PANDEMIC IN VARIOUS PERSPECTIVES
}

\author{
Afifa Rangkuti
}

Faculty of Sharia and Law, Universitas Islam Negeri Sumatera Utara afifa.rangkuti.darbi@gmail.com

\begin{tabular}{l} 
ABSTRACT \\
\hline Various sectors were affected, especially sectors in the economic sector. Not \\
only the economic sector, the government sector also experienced the \\
impact. One of the sectors in the government category is the pilkada or \\
regional head elections (Pilkada). Pilkada in accordance with the \\
plan will be held simultaneously in 2020. However, the national situation \\
which is being hit by the Covid-19 outbreak has forced the phases of the \\
Pilkada to be delayed. This year's Pilkada cannot be implemented or \\
postponed due to the impact of Covid-19 that is hitting Indonesia. However, \\
the health protocol requirements must be implemented, such as wearing a \\
mask, washing hands with soap, keeping your distance, using a hand \\
sanitizer and personal protective equipment or APD. The Pilkada this year \\
cannot be held simultaneously. The Method use in this research is normative \\
legal research. The result showed that the total number of regions that will \\
carry out the Pilkada simultaneously in 2020 is 270 regions, with details of \\
9 provinces, 224 regencies and 37 cities. However, this year's Pilkada \\
cannot be implemented or postponed due to the impact of Covid-19 that is \\
hitting Indonesia. This was done as an effort to anticipate the spread of \\
the corona virus.. \\
Keywords: Delay, Pilkada, Covid Pandemic 19. \\
Journal History \\
Received : August 19, 2020; \\
Reviewed : October 10, 2020; \\
Accepted : October 28, 2020; \\
Published : November 1, 2020 \\
Copyright @2020 NLR. All right reserved. \\
\hline
\end{tabular}




\section{INTRODUCTION}

Democracy is something that is universal, because in general modern countries classify themselves as countries that uphold democracy, even though the implementation mechanisms, both involving political infrastructure and supra political structure, differ from one another, this is more due to differences in life views. from each country. The modern constitutional state always has a nationalist or national background and tends to be democratic. ${ }^{1}$

General elections are the main mechanism involved in the stages of state administration and government formation. General elections are seen as the most obvious form of sovereignty in the hands of the people in the administration of the State. Therefore, the system and administration of general elections has always been the main concern of the Government so that the guidelines from, by, and for the people are expected to really be realized through the structuring of the system and the quality of general election administrators. Because it is a measure of the degree of democracy of a country, the implementation of elections (legislative, presidential elections and regional head elections (pilkada) / post-conflict local elections) must be carried out in a

\begin{tabular}{lr}
\hline Eka & N.A.M Sihombing, \\
Pemberlakuan & "Parliamentary \\
Threshold" dan Kaitannya dengan Hak
\end{tabular}

good, honest and fair manner, without coercion against individuals as has happened in the past. Moreover, the holding of elections is to elect leaders and establish other democratic institutions. In the context of local democracy, regional head elections (pilkada) or regional head elections (pemilukada) are efforts to find quality regional leaders in peaceful, honest and fair ways. One of the most important principles of democracy therein is recognition of differences and peaceful solutions. The implementation of regional elections cannot be separated from its basic foundation related to the implementation of regional government that uses the principle of regional autonomy, while the development of regional autonomy as part of decentralization will always be related to the success of the reform order which has made the implementation of the principle of regional autonomy in Indonesia increasingly improved, and opens up space for area to create independently. At the beginning of the reform, the foundation of the regional autonomy regulation was Law 22/1999 on the implementation of regional government (regional autonomy), it turns out that the process of implementing regional head elections (pilkada) is still elected by DPRD members.

Asasi Manusia, Jurnal Konstitusi, Vol. 1, No. 1, Juni (2009), p. 26-27. 
Amendments to the Constitution of the Republic of Indonesia in 1945 were the culmination of a fundamental change achieved by the power of the people after the New Order government. Amendments to the 1945 Constitution of the Republic of Indonesia have made major changes, especially in the general election. ${ }^{2}$

In the provisions of Article 1 number 1 of Law Number 10 of 2008 concerning General Election of Members of the People's Representative Council, Regional Representative Council, and Regional People's Representative Council, it is stated: General election is a means of exercising people's sovereignty which is carried out directly, publicly, freely, in secret, honest and fair in the Unitary State of the Republic of Indonesia based on Pancasila and the 1945 Constitution of the Republic of Indonesia. So that all election implementation processes must be carried out according to the principles of direct, general, free, secret, honest and fair elections. Therefore, the implementation of elections in Indonesia should follow the principles contained therein. ${ }^{3}$

This process has changed since the amendment to the 1945 Constitution was carried out in the 1999-2004 DPR / MPR period which made the implementation of a direct presidential election, so that it

2 Mhd. Ansor Lubis. Fifth Amendment Consolidation Of The 1945 Constitution Of The Republic Of automatically affected the implementation mechanism for regional head elections (pilkada) to be carried out directly and began to be implemented in 2005. Covid outbreak -19 was officially announced on March 15, 2020. A number of policies were implemented, such as physical distancing, work from home, until the PSBB (Large-Scale Social Restrictions) was implemented by the government to prevent the expansion of the spread of the corona virus in Indonesia. This pandemic is not only requires people to keep their distance and healthy behavior, but the impact is shifting or postponement of the agenda n national Program which has been scheduled. Various sectors have been affected, especially sectors in the economic sector. Not only the economic sector, the government sector also experienced the impact. One of the sectors in the government category is the pilkada or regional head elections. Pilkada in accordance with the plan will be held simultaneously in 2020. However, the national situation which is being hit by the Covid-19 outbreak has forced the phases of the Pilkada to be delayed. In the midst of the Covid-19 outbreak, the impact was felt on society, especially the Indonesian people. This year's Pilkada cannot be held simultaneously. The total number of regions that will carry out

Indonesia. Nomoi Law Review. Vol. 1. No. 1. (May, 2020).

${ }^{3}$ Eka NAM Sihombing, Op. Cit., p. 31 . 
the Pilkada simultaneously in 2020 is 270 regions, with details of 9 provinces, 224 regencies and 37 cities. However, this year's Pilkada cannot be implemented or postponed due to the impact of Covid-19 that is hitting Indonesia. This is done as an effort to anticipate the spread of the virus. Simultaneous Regional Head Elections (Pilkada) in 2020. General elections for the first time in the history of Indonesian independence which was only 10 (ten) years old at that time were held in 1955. The next series of general elections were held again during the New Order period, namely the general elections of 1971, 1977, 1982, 1987, 1992 and 1997.

As the reason for holding general elections is to gain recognition or trust from the public, including the international community, because the government and other institutions that were products of the 1997 general election are considered to be distrusted. The holding of direct elections for the President and Vice President in 2004 has inspired the direct elections for Regional Heads and Deputy Regional Heads (Pilkada). This is also supported by the spirit of regional autonomy that was introduced in 1999. Therefore, since 2005, direct regional head elections have been held, both at the provincial and district / city levels. Regional head elections are direct elections for regional heads by the community as a manifestation of democracy. Prior to 2005 regional head elections were elected by the Regional People's Representative Council (DPRD). Since the enactment of Law Number 32 of 2004 concerning Regional Government, regional heads are directly elected by the people through the Election of Regional Heads and Deputy Regional Heads or abbreviated as Pilkada and for the first time it was held in June 2005. The election of a direct regional head election system is a correction to the previous pilkada which used a representative system by the Regional People's Representative Council. The use of this direct election system shows the development and arrangement of the format of regional democracy that is developing within the framework of political liberalization. ${ }^{4}$

Because it is a measure of the degree of democracy of a country, the implementation of elections (legislative, presidential elections and regional head elections (pilkada) / post-conflict local elections) must be carried out in a good, honest and fair manner, without coercion against individuals as has happened in the past. Moreover, the holding of elections is to elect leaders and establish other democratic

4 Tjahjo Kumolo, Politik Hukum Pilkada Serentak, (Jakarta; PT Mizan Republika, 2015), hlm. 76. 
institutions. In the context of local democracy, regional head elections (pilkada) or regional head elections (pemilukada) are efforts to find quality regional leaders in peaceful, honest and fair ways. One of the most important principles of democracy therein is recognition of differences and peaceful solutions.

In the context of local democracy, regional head elections (pilkada) or regional head elections (pemilukada) are efforts to find quality regional leaders in peaceful, honest and fair ways. One of the most important principles of democracy therein is recognition of differences and peaceful solutions. In 2020, a simultaneous regional election will be held which will be participated by 270 regions. This simultaneous regional election is the fourth batch of regional heads from the election results in December 2015. The regions consist of 9 provinces, 224 regencies and 37 cities. The simultaneous regional elections in 2020 should have been followed by 269 regions, but it became 270 because the Pilkada of Makassar City was repeated. The simultaneous regional elections in 2020 are deemed necessary to be held by reflecting on the experience of administering the 2019 Election, where several technical and human resource

5 Herman Ibrahimm, Faisal Siagian, Pemilu dan Reformasi Sistem Kepartaian, Menuju Masyarakat Madani problems made the election less effective. $^{5}$

\section{DISCUSSION}

Impact of Covid-19 on the Implementation of Simultaneous Regional Head Elections (Pilkada) in 2020 .

Reform of the constitution marked by an amendment to the 1945 Constitution of the Republic of Indonesia in the period 1999-2002, has implications for the structure in the constitutional system of the Republic of Indonesia. This very fundamental change also gave birth to many new state institutions, which were expected to be able to sustain in aspects of national and state life. One of the state institutions that was born from the womb of reform is the Constitutional Court (MK), where the state institution has a position as a constitutional court. The rule of law is termed rechstaats or the rule of law. In Indonesia, the founding of the state from the beginning has been advocated by the founding father as a state of law. In the context of the third amendment to the 1945 Constitution Article 1 paragraph (3) it is emphasized that "the State of Indonesia is a State of Law". Even though it has been explicitly stated in the constitution as a state based on law, the blueprint and macro design elaborating the idea of the rule of law have not been explicitly formulated

yang Dicita- citakan, (Jakarta: Biro Humas Depdagri, 1999), hlm. 53-57. 
comprehensively. With the existence of several principles in a rule of law proposed by Julius Stahl and AVDicey, it can be formulated one of the main principles of the rule of law as the main pillars that support the establishment and establishment of a modern state called the rule of law or rechtsstaat), is the protection of the rights of citizens. ${ }^{6}$

R. Herlambang Perdana Wiratraman in Rudy Hendra Pakpahan, Eka NAM Sihombing, in the 1945 Constitution, there is a conception of state responsibility in human rights (state responsibilities), as seen in articles 28I (4) and (5), which state " The protection, promotion, upholding and fulfillment of human rights are the responsibility of the state, especially the government and to uphold and protect human rights in accordance with the principles of a democratic rule of law, the implementation of human rights is guaranteed, regulated and set forth in statutory regulations. . " Both are key in seeing the constitutional responsibility that must be carried out by the state, in this case the government, to carry out efforts to promote human rights. ${ }^{7}$

\section{${ }^{6}$ Andryan, Eka NAM Sihombing,Penguatan Mahkamah Konstitusi Republik Indonesia Melalui Constitutional Complaint, Jurnal Hukum Perancangan Peraturan Perundang- undangan, Vol. 4 No. 2, November (2018). \\ ${ }^{7}$ Rudy Hendra Pakpahan, Eka N.} A. M. Sihombing, Tanggung Jawab Negara Dalam Pelaksanaan Jaminan
Human rights in Indonesia originate from and lead to Pancasila. Which means that human rights have a strong guarantee from the nation's philosophy, namely Pancasila. Leading to Pancasila, it means that the implementation of human rights must pay attention to the lines that have been determined in the provisions of the Pancasila philosophy. For the Indonesian people, exercising human rights does not mean exercising freely, but must pay attention to the provisions contained in the Indonesian people's view of life, namely Pancasila. This is due to the fact that basically there are no rights that can be exercised in multiple ways without considering the rights of others. Each right will be limited by the rights of others. If in exercising our rights, we do not pay attention to the rights of others, then what will happen is a conflict of rights or interests in the life of the community, nation and state. ${ }^{8}$

The Covid-19 outbreak was officially announced on March 15, 2020. A number of policies were implemented, such as physical distancing, work from home, until the PSBB (Large-Scale Social Restrictions) were implemented by

Sosial (Responsibility State In The Implementation Of Sosial Security), Jurnal Legislasi Indonesia, Vol. 9 No. 2 - Juli (2012), p. 174.

8 Eka N.A.M Sihombing,

Pemberlakuan "Parliamentary Threshold" dan Kaitannya dengan Hak Asasi

Manusia, Jurnal Konstitusi, Vol. 1, No. 1, Juni (2009), p. 28. 
the government to prevent the expansion of the spread of the corona virus in Indonesia. This pandemic is not only requires people to keep their distance and healthy behavior, will be but the impact is shifting or postponement of the national agenda and the international agenda has been scheduled. Various sectors were affected, especially sectors in the economic sector. Not only the economic sector, the government sector also experienced the impact. One of the sectors in the government category is the pilkada or regional head elections. Pilkada in accordance with the plan will be held simultaneously in 2020. However, the national situation which is being hit by the Covid-19 outbreak has forced the phases of the Pilkada to be delayed. At the hearing (RDP) of the KPU, Banwaslu, DKPP, and the Minister of Home Affairs with the DPR on March 30, 2020, it was concluded that Commission II of the DPR RI approved the funding for the 2020 concurrent Regional Head Election (Pilkada) stages that have not been completed and cannot be implemented. One of them is the 2020 Pilkada held in March 2021, or delayed 6 months from the predetermined time. The

9 Amirudin, A. Zaini Bisri, Pemilihan kepala daerah (Pilkada) Langsung Problem dan Prospek, (Yogyakarta: Pusataka Pelajar, 2006), hlm. 12.

10 Cynthia Hadita, Regional Autonomy Political Politics Of Regional meeting ni not yet decided the time is ideal for the implementation of the organization of the elections in 2020. The results of this meeting then raises many questions among the public, especially the civil society (NGO) activists elections on time penyel enggaraan masi Election 2020 unclear. $^{9}$

Karianga in Hadita (2020) Associated with the use of moral responsibility in the office, Roscoe Pound pointed out that in a society which people may assume that people who are on around him are people who civilized, as a result, in the event of an act that deviates would hold accountablethe parties that did such acts, as a result, in the view of Roscoe Pound there are four things that become the basis forapplying the moral responsibility, namely: ${ }^{10}$

1. That other people will have the hope of a good and reasonable that created $t$ he appointment or conduct of the person's official;

2. That officials will keep its promise is based on the hope that is attached to it by a sense of morality on the citizens;

Liability Reports To Regional Representatives In The Implementation Of Local Government, Nomoi Law Review, Volume 1, Issue 1, May 2020, p. 94. 
3. That they will act diligently and can be trusted in the interaction of position and work;

4. That they will refurbish anything that has ac ceptance of error or circumstances which d o

not unexpectedly been acceptance of erroneous or circumstances that are not presumed - would have thought, so they accept anything $\mathrm{t}$ hat should not

be worthy and not will be received in ordinary circumstances.

Which on a more complex level will result in internal party conflicts or even to the point of spreading out the community order.When viewed in a historical approach, the highly centralized New Order power provides a trail of local politics that can be divided into two things: (i) elite-led local political control which is a national and regional collaboration or (ii) the emergence of powerful people in the region. The truth is that democratic governance by local people is not really achieved.In reality today it can be seen clearly through the candidacy of regional head candidates in various regions in Indonesia. Specifically, the process of carrying out regional head candidates for the 2020 Regional Head Elections in Medan, there are

11 Benito Asdhie Kodiyat MS, Abdul Hakim Siagian, Andryan, The Effect of Centralistic Political Party Policies in Selection Of Regional Heads indications of the strengthening of the centralization of political party policy in determining the regional head candidates who will advance to the simultaneous local elections. So far, the political reality of the nomination of regional heads in Medan City only shows one candidate (independent) who will participate in the election of regional heads (Mayor) in Medan City.This is influenced by the indications of the centralistic policy of political parties at the national level which in their decision making does not heed the arguments of political parties at the local level. When in fact, the reform agenda that includes the legal politics of strengthening the position of the region with the application of the principle of decentralization-autonomy in the implementation of government, must be accompanied by the authority of decentralization-autonomous

determination and selection of prospective regional leaders. Somewhat difficult to imagine, the realization of decentralizationregional autonomy will be successfully achieved if in the process of determining regional leaders are still in the shadow of the national political elite. More broadly, this does not provide an opportunity for the people of the region to freely determine their future leaders in the area. To a certain degree, this kind of process will destroy regional democratization. ${ }^{11}$

in Medan City, Indonesian Journal of Education, Social Sciences and Research (IJSSR), Vol. 1, No. 1, June 2020, p. 61. 
DPR Commission II plans to hold another Hearing Meeting (RDP) to determine a mutually agreed time for the Pilkada. On April 14, 2020, Commission II of the Indonesian House of Representatives (DPR RI) again held an RDP with the KPU, DKPP, and the Ministry of Home Affairs to agree on the date for the simultaneous

Pilkada 2020. Commission II of the DPR RI approved the Government's proposal (which was attended by the Minister of Home Affairs) to postpone the simultaneous Pilkada implementation. 2020 will be December 9, 2020. The approval was revealed in the Work Meeting of the Commission II of the DPR RI with the Minister of Home Affairs and the Hearing Meeting (RDP) with the ranks of the General Election Commission (KPU), the Election Supervisory Board (Bawaslu), and the Honorary Council of Election Administrators (DKPP). The results of this meeting are final and the government must immediately provide a legal umbrella. The Covid19 outbreak not only forced the implementation of the 2020 regional elections to be postponed. More than that, this pandemic has hit a state law relating to regional elections. Article 201 paragraph 6 states that, "the simultaneous voting for the Governor and Deputy Governor, the Regent and Deputy Regent, as well as the Mayor and Deputy Mayor of the 2015 elections will be held in September 2020". This article gives the KPU a direct mandate to determine the election date. The final decision for the simultaneous voting was September 23, 2020. Regarding the reason for the election date, the Chairman of the KPU said there were two reasons. The first is the custom of choosing Wednesday as the voting day. Secondly, choosing a date with two-digit numbers to avoid a date that coincides with the voting date, for example, September 2, 2020. ${ }^{12}$

The state in the federal state has the right to choose the leader in the state through simultaneous elections or not. Whereas the unitary state has the choice of legislative and / or executive elections in the regions and how the implementation is a consequence of policy, whether to use autonomy or not. Thus, it can be concluded that the existence of executive and legislative elections at the national level is a consequence of the government system. Whereas the existence of elections at the local level is a consequence of the choice of the form of state and the sub-national governance management system chosen.In the context of Indonesia, the form of state and sub-national government management system adopted is a unitary state by implementing regional autonomy. This has the consequence that regional leaders are chosen from and by the regions themselves. Next, the management of the region becomes a powerful authority of the region itself (autonomous). The autonomy of the sub-national government management system cannot be

${ }^{12}$ Ibid, hlm. 13. 
separated from the regional political agenda in the case of regional head elections. This is because regional head elections are the basis and foundation of regional government management, which can be said that regional head elections are an essential factor in the regional government system. Therefore, in the context of the candidacy of the regional head candidacy which is currently experiencing an imbalance of the system, where political parties centrally control the policy making to elect candidates for regional heads who incidentally ignores the aspirations of the region (party regional administrators), even though the fact is that constitutionally the regions are an autonomous region that has its own authority to develop its region. This becomes the ambivalence of the system that will destroy democracy itself, moreover that the general knowledge of the community considers that political parties are pillars of democracy. Then, how is it possible for a system to run consistently if there is a system deviation in the body of the system (political parties). ${ }^{13}$

When Covid-19 entered Indonesia and was officially announced on March 15, 2020, there were practically a phase that was postponed by the KPU. There were four stages that were officially postponed. The four stages postponed by the KPU, namely, Voting Inauguration (PPS), verification of the support requirements of individual candidates, establishing voter data updating officers, and updating and compiling voter lists. This practically delays other stages, such as candidate registration, nomination of candidates, to voting. This delay creates a mismatch in the law. In legal terms it is known as das sollen (legal regulations) and das sein (concrete events). The Das Sein which happened today has made the das sollen which is in Law no. 10 of 2016 concerning the Election of Governors, Regents, and Mayors cannot be applied properly. Of course, this creates legal uncertainty and is dangerous for the operation of a constitutional system.

\section{Impact of the Postponement of the 2020 Regional Head Elections (Pilkada)}

In the midst of the Covid-19 outbreak, the impact was felt on society, especially the Indonesian people. This year's Pilkada cannot be held simultaneously. The total number of regions that will carry out the Pilkada simultaneously in 2020 is 270 regions, with details of 9 provinces, 224 regencies and 37 cities. However, this year's Pilkada cannot be implemented or postponed due to the impact of Covid-19 that is hitting Indonesia. This is done as an effort to anticipate the spread of the virus. With the impact of the rapid spread of Covid-19 in Indonesia, the

${ }^{13}$ Ibid. 
Government and DPR officially postponed the implementation of the Pilkada in September 2020. KPU as a whole does not have full authority over the postponement of elections and election stages, because it is the authority of the Lawmakers and still needs to coordinate with the Minister of Home Affairs. in deciding the postponement of the Pilkada. Therefore, it is necessary to have a Regulation in Lieu of Law (Perppu) so that the 2020 Pilkada postponement policy has a clear legal umbrella. In a situation like this, the President as the head of state has the authority to make decisions because the situation is urgent and compelling. As stated in the decision of the Constitutional Court (MK) Number 138 PUU / VIII / 2009 regarding the requirements for the issuance of a Perppu. The Perppu also functions as an alternative legal guide for the KPU in carrying out its duties as an election committee. In line with that, Minister of Home Affairs Tito Karnavian has ordered his staff to immediately coordinate with relevant ministries, especially with the State Secretariat to begin drafting the 2020 Pilkada Perppu as an amendment to Law 10/2016 which regulates the 2020 Pilkada. ${ }^{14}$

In addition, the central government also needs to review the Regional Head Decree

${ }^{14}$ Gaffar Janedjri, Politik Hukum Pemilu, (Jakarta: Konstitusi Press, 2012), hlm. 1. that will expire in 2020. Options that can be taken are to extend the SK or prepare a temporary Acting Officer to carry out the duties of the regional head. This is done to minimize problems that will arise due to the absence of legal certainty that legitimizes the status of regional heads and may confuse the bureaucracy. Not only that, political parties will certainly move to sue the regional heads and the central government to take action against the Regional Head Decree because it is considered administratively problematic. The DPR RI and the Minister of Home Affairs also need to pay attention to the vacant leadership of regional heads that will emerge if the SK extension is not an option. Because when there is no SK extension, there will be a leadership vacuum and will hinder the performance of the bureaucracy. Therefore, in these three months there must be legal certainty so that performance is in direct contact with community services. Do not let community services stop because there is no legal certainty regarding the option of replacing regional heads or extending decrees, especially in the midst of the Covid19 pandemic situation which has undermined many lines of community life. 
The General Election Commission (KPU) has three choices of dates that can be used as voting days. This was conveyed by Arief Budinman after coordinating with Commission II of the DPR and the Minister of Home Affairs. The first option is on 9 December 2020 with a delay period of 3 months. The second option 17 March 2021 with a delay of 6 months. The third option is 29 September 2021 with a delay of 1 year. However, the first option was chosen and could be the priority option if the Covid-19 pandemic conditions gradually recovered. ${ }^{15}$ In addition, the postponement of the 2020 Pilkada will also have an impact on the recruitment of ad hoc officers for regional head elections. The impact could be with the recruitment that will be postponed and the temporary dismissal of the performance of ad hoc officers and the absence of any honorarium that will be given because of the tasks that have not been carried out. However, of course there is a consequential impact of the simultaneous postponement of regional elections in the 9 provinces, 224 districts and 37 cities. The delay will impact on the budget that has been disbursed and the condition of the human resources (HR) of the organizers. In fact, the government could save the

15 Syaukani, Otonomi Daerah Dalam Negara Kesatuan, (Yogyakarta: Pusataka Pelajar, 2004), hlm. 12.

${ }^{16}$ Joko J. Prihatmoko, Pemilihan Kepala Daerah Langsung, Filosofi, state budget by not providing or postponing the provision of honoraria as determined in the decree. It is sufficient for the state to only prioritize the budget for each region by paying for activities that have been carried out by the KPU in each region. The rest of the budget can be used to prepare for economic recovery after the Covid-19 pandemic is over or it can be relocated to the Covid-19 pandemic relief aid budget. ${ }^{16}$ Moreover, there is a prediction that this pandemic will only finish in September 2020 and January 2021 at the latest. So, it is possible that KPU activities, especially the recruitment of ad hoc personnel and the new election stages could be carried out in 2021. If we look closely, the decision to postpone the Pilkada is the best decision so that the country's concentration is not divided. In a situation like this, the country must focus on handling Covid-19, whose positive confirmation has reached more than 6,000 . If the concentration is divided, the performance of the KPU and the Government could be neglected and the results of the performance made by the government may not reap the maximum results.

Sistem dan Problem Penerapan Di Indonesia, Semarang; LP3M Universitas Wahid Hasyim, 2005, hlm: 3-6 


\section{CONCLUSION}

General elections are the main mechanism involved in the stages of state administration and government formation. General elections are seen as the most obvious form of sovereignty in the hands of the people in the administration of the State. However, this year's Pilkada cannot be implemented or postponed due to the impact of Covid-19 that is hitting Indonesia. The Covid-19 outbreak not only forced the implementation of the 2020 regional elections to be postponed. More than that, this pandemic has hit a state law related to the implementation of regional elections. In the midst of the Covid-19 outbreak, its impact has been felt on the community, especially the Indonesian people. This year's Pilkada cannot be held simultaneously. The total number of regions that will carry out the Pilkada simultaneously in 2020 is 270 regions, with details of 9 provinces, 224 regencies and 37 cities. However, this year's Pilkada cannot be implemented or postponed due to the impact of Covid-19 that is hitting Indonesia. This is done as an effort to anticipate the spread of the virus. With the impact of the rapid spread of Covid-19 in Indonesia, the Government and DPR officially postponed the implementation of the Pilkada in September 2020. In this situation, the President as head of state has the authority to make decisions because it is in a precarious and compelling situation. As stated in the decision of the Constitutional Court (MK) Number 138 PUU / VIII / 2009 regarding the conditions for issuing a Perppu. The Perppu also functions as an alternative legal guide for the KPU in carrying out its duties as an election committee. Therefore, in these three months there must be legal certainty so that performance is in direct contact with community services. Do not let community services stop because there is no legal certainty regarding options for replacing regional heads or extending SKs, especially in the midst of the Covid-19 pandemic situation which has undermined many lines of community life. Because it is acknowledged or not, the key to postponing the 2020 Pilkada lies in the legal umbrella which legitimizes this and this is what the government and current lawmakers must prioritize for some time to come.

\section{REFERENCES}

Amirudin, A. Zaini Bisri, Pemilihan kepala daerah (Pilkada) Langsung Problem dan Prospek, Yogyakarta: Pusataka Pelajar, 2006.

Andryan, Eka NAM Sihombing,Penguatan

Mahkamah

Konstitusi Republik Indonesia Melalui Constitutional Complaint, Jurnal Hukum Perancangan Peraturan Perundangundangan, Vol. 4 No. 2, November (2018).

Hadita, Cynthia., Regional Autonomy Political Politics Of Regional 
Liability Reports To Regional

Representatives In The

Implementation Of Local

Government, Nomoi Law

Review, Volume 1, Issue 1, May 2020.

Ibrahim, Herman. Faisal Siagian,

Pemilu dan Reformasi Sistem

Kepartaian, Menuju

Masyarakat Madani yang

Dicita- citakan, Jakarta: Biro

Humas Depdagri, 1999.

Janedjri, Gaffar. Politik Hukum

Pemilu, Jakarta: Konstitusi Press, 2012.

Kodiyat MS, Benito Asdhie., Abdul Hakim Siagian, Andryan, The Effect of Centralistic Political Party Policies in Selection Of Regional Heads in Medan City, Indonesian Journal of Education, Social Sciences and Research (IJSSR), Vol. 1, No. 1, June 2020.

Kumolo, Tjahjo. Politik Hukum Pilkada Serentak, Jakarta; PT Mizan Republika, 2015.

Lubis, Mhd. Ansor. Fifth Amendment Consolidation Of The 1945 Constitution Of The Republic Of Indonesia. Nomoi Law Review. Vol. 1. No. 1. (May, 2020).

Pakpahan, RH., Eka N. A. M. Sihombing, Tanggung Jawab Negara Dalam Pelaksanaan Jaminan Sosial (Responsibility State In The Implementation of Sosial Security), Jurnal Legislasi Indonesia, Vol. 9 No. 2 - Juli (2012).

Prihatmoko, Joko J. Pemilihan Kepala Daerah Langsung, Filosofi, Sistem dan Problem Penerapan Di Indonesia,
Semarang; LP3M Universitas Wahid Hasyim, 2005.

Sihombing, Eka N.A.M., Pemberlakuan "Parliamentary Threshold" dan Kaitannya dengan Hak Asasi Manusia, Jurnal Konstitusi, Vol. 1, No. 1, Juni (2009).

Syaukani, Otonomi Daerah Dalam Negara Kesatuan, Yogyakarta: Pusataka Pelajar, 2004. 